\title{
A Proton-Coupled Transport System for $\beta$-Hydroxy- $\beta$-Methylbutyrate (HMB) in Blood-Brain Barrier Endothelial Cell Line hCMEC/D3
}

\author{
Kei Higuchi ${ }^{1,+}$, Sathish Sivaprakasam ${ }^{1}{ }^{\mathbb{D}}$, Souad R. Sennoune ${ }^{1}$, Jiro Ogura ${ }^{1, \ddagger}$, Yangzom D. Bhutia ${ }^{1}$, \\ Ricardo Rueda $^{2}$ D, Suzette L. Pereira ${ }^{3}(D)$ and Vadivel Ganapathy ${ }^{1, *}$
}

1 Department of Cell Biology and Biochemistry, Texas Tech University Health Sciences Center, 3601 4th Street, Lubbock, TX 79430, USA; higuchi@toyaku.ac.jp (K.H.); sathish.sivaprakasam@ttuhsc.edu (S.S.); souad.Sennoune@ttuhsc.edu (S.R.S.); jiro.ogura@med.id.yamagata-u.ac.jp (J.O.); yangzom.D.Bhutia@ttuhsc.edu (Y.D.B.)

2 Abbott Nutrition, Research \& Development, 18004 Granada, Spain; ricardo.rueda@abbott.com

3 Abbott Nutrition, Research \& Development, Columbus, OH 43219, USA; suzette.pereira@abbott.com

* Correspondence: Vadivel.ganapathy@ttuhsc.edu

+ Current address: Department of Pharmaceutics, School of Pharmacy, Tokyo University of Pharmacy and Life Sciences, Tokyo 192-0392, Japan.

$\ddagger$ Current address: Vice Director of Pharmacy, Yamagata University Hospital, Yamagata 990-8560, Japan.

\section{check for} updates

Citation: Higuchi, K.; Sivaprakasam, S.; Sennoune, S.R.; Ogura, J.; Bhutia, Y.D.; Rueda, R.; Pereira, S.L.; Ganapathy, V. A Proton-Coupled Transport System for

$\beta$-Hydroxy- $\beta$-Methylbutyrate (HMB) in Blood-Brain Barrier Endothelial Cell Line hCMEC/D3. Nutrients 2021, 13, 3220. https://doi.org/10.3390/ nu13093220

Academic Editor: Maret G. Traber

Received: 18 August 2021

Accepted: 14 September 2021

Published: 16 September 2021

Publisher's Note: MDPI stays neutral with regard to jurisdictional claims in published maps and institutional affiliations.

Copyright: (c) 2021 by the authors Licensee MDPI, Basel, Switzerland. This article is an open access article distributed under the terms and conditions of the Creative Commons Attribution (CC BY) license (https:// creativecommons.org/licenses/by/ $4.0 /)$.

\begin{abstract}
Hydroxy- $\beta$-methylbutyrate (HMB), a leucine metabolite, is used as a nutritional ingredient to improve skeletal muscle health. Preclinical studies indicate that this supplement also elicits significant benefits in the brain; it promotes neurite outgrowth and prevents age-related reductions in neuronal dendrites and cognitive performance. As orally administered HMB elicits these effects in the brain, we infer that HMB crosses the blood-brain barrier (BBB). However, there have been no reports detailing the transport mechanism for $\mathrm{HMB}$ in $\mathrm{BBB}$. Here we show that $\mathrm{HMB}$ is taken up in the human BBB endothelial cell line hCMEC/D3 via $\mathrm{H}^{+}$-coupled monocarboxylate transporters that also transport lactate and $\beta$-hydroxybutyrate. MCT1 (monocarboxylate transporter 1) and MCT4 (monocarboxylate transporter 4) belonging to the solute carrier gene family SLC16 (solute carrier, gene family 16) are involved, but additional transporters also contribute to the process. HMB uptake in BBB endothelial cells results in intracellular acidification, demonstrating cotransport with $\mathrm{H}^{+}$. Since HMB is known to activate mTOR with potential to elicit transcriptomic changes, we examined the influence of HMB on the expression of selective transporters. We found no change in MCT1 and MCT4 expression. Interestingly, the expression of LAT1 (system L amino acid transporter 1), a high-affinity transporter for branched-chain amino acids relevant to neurological disorders such as autism, is induced. This effect is dependent on mTOR (mechanistic target of rapamycine) activation by HMB with no involvement of histone deacetylases. These studies show that HMB in systemic circulation can cross the BBB via carrier-mediated processes, and that it also has a positive influence on the expression of LAT1, an important amino acid transporter in the BBB.
\end{abstract}

Keywords: $\beta$-hydroxy- $\beta$-methylbutyrate; MCT1 (SLC16A1); MCT4 (SLC16A3); LAT1 (SLC7A5); mTOR; blood-brain barrier

\section{Introduction}

$\beta$-Hydroxy- $\beta$-methylbutyrate $(\mathrm{HMB})$ is an endogenous minor metabolite of the essential amino acid leucine, a branched-chain amino acid like valine and isoleucine. The metabolism of all three branched-chain amino acids occurs robustly not only in the liver, but also in the skeletal muscle, brain, and retina [1-3]. There are several pathways for the metabolism of leucine, and only $<10 \%$ of leucine goes through the pathway that produces HMB. As such, the circulating levels or tissue levels of HMB are in the low micromolar range under normal physiological conditions. Interestingly, this minor metabolite has 
been found to have a significant impact on the cellular signaling pathways associated with anabolic metabolism, but only at supra-physiological concentrations [4-6]. The most notable of these pharmacological effects of HMB is the stimulation of protein synthesis in skeletal muscle via the activation of signaling pathways involving phosphoinositide-3kinase (PI3K), mitogen-activated protein kinases (MAPK), extracellular signal-regulated kinases (ERK1), and mTOR (mechanistic target of rapamycin). Therefore, HMB is used at supra-physiological (or therapeutic) doses as a nutritional ingredient to improve muscle health, particularly for conditions such as sarcopenia and muscle wasting. It is also used by athletes to enhance muscle mass and strength. A recent report has shown that HMB also protects against diet-induced obesity; interestingly, the mechanism responsible for this phenomenon is HMB-induced alterations in colonic bacteria, consequently increasing the luminal concentrations of the short-chain fatty acid propionate [7]. Propionate is a known inhibitor of histone deacetylases [8,9] and also an agonist for the G-protein-coupled receptor GPR43 $[10,11]$. The anti-obesity effect of orally administered HMB might arise from the influence of bacteria-generated propionate on organs such as the intestinal tract, liver and adipocytes.

The biological effects of HMB are not restricted to the peripheral tissues. Orally administered HMB has been shown to have a broad spectrum of beneficial effects in the brain, as evident from in vitro and in vivo studies [12-14]. In vitro, HMB promotes differentiation and neurite outgrowth in the mouse neuroblastoma cell line Neuro2a in culture [12]. In vivo, HMB prevents the age-related loss of dendrites in pyramidal neurons in rats [13], and also ameliorates age-related decline in cognitive performance in rats [14]. As in vivo effects are seen with $\mathrm{HMB}$ administered to the animals orally, it is inferred that HMB is able to cross the blood-brain barrier (BBB), but there have been no published reports in the literature describing the transport of HMB in BBB endothelial cells. Recently, we reported that HMB is transported into skeletal muscle cells via the $\mathrm{H}^{+}$-coupled monocarboxylate transporters MCT1 (monocarboxylate transporter 1) and MCT4 (monocarboxylate transporter 4) [15]. BBB endothelial cells express $\mathrm{H}^{+}$-coupled monocarboxylate transporters [16-18] and play a key role in the transport of physiologically important monocarboxylates such as lactate and $\beta$-hydroxybutyrate (a ketone body), which are transferred from the systemic circulation into the brain across the BBB and function as alternative energy substrates to neurons when glucose supply is limited $[19,20]$. Therefore, we hypothesized that the same transporters in BBB endothelial cells are also involved in the cellular uptake of $\mathrm{HMB}$, a monocarboxylate structurally similar to lactate and $\beta$ hydroxybutyrate. We tested this hypothesis in vitro using the human brain microvascular endothelial cell line hCMEC/D3.

$\mathrm{HMB}$ is also known for its intracellular actions as a signaling molecule. Its ability to promote anabolism is related to mTOR signaling [4-6]. This suggests that HMB might potentially elicit changes in the transcriptomic profile in target cells. As such, we examined the impact of HMB on the expression of selective transporters in hCMEC/D3 cells.

\section{Materials and Methods}

\subsection{Materials}

The human cerebral microvascular endothelial cell line hCMEC/D3 was purchased from EMD Millipore-Sigma (Burlington, MA, USA). The human breast cancer cell line MCF7 and mouse skeletal muscle cell line $\mathrm{C} 2 \mathrm{C} 12$ were obtained from the American Type Culture Collection (ATCC, Manassas, VA, USA). Cell culture media, except for the one used for culturing hCMEC/D3 cells, were obtained from Corning Cellgro (Manassas, VA, USA) and the fetal bovine serum (FBS) was from Atlanta Biologicals (Norcross, GA, USA). L- $\left[{ }^{14} \mathrm{C}(\mathrm{U})\right]$-Lactate (specific radioactivity, $150 \mathrm{mCi} / \mathrm{mmol}$ ) was purchased from Perkin Elmer (Waltham, MA, USA). $\left[1-{ }^{14} \mathrm{C}\right]-\beta$-Hydroxy- $\beta$-methylbutyrate was custom-synthesized by the American Radiolabeled Company (St. Louis, MO, USA). The MCT1-specific inhibitor SR13800 (2,6-dihydro-7-[(3-hydroxypropyl)thio]-2-methyl4-(2-methylpropyl)-6-(1-naphthalenylmethyl)-1H-pyrrolo[3,4-d]pyridazin-1-one) and the 
MCT4-specific inhibitor Bindarit were obtained from EMD Millipore-Sigma and Advanced ChemBlocks Inc (Burlingame, CA, USA), respectively. All other reagents were from Thermo Fisher Scientific (Waltham, MA, USA), Sigma Aldrich (St. Louis, MO, USA), or Tokyo Chemical Industry (Tokyo, Japan).

\subsection{Cell Lines and Culture Conditions}

The hCMEC/D3 cells were maintained in EndoGRO medium supplemented with $5 \%$ FBS, $0.2 \%$ EndoGRO-LS supplement, $5 \mathrm{ng} / \mathrm{mL}$ rhEGF, $10 \mathrm{mM}$ L-glutamine, $1 \mu \mathrm{g} / \mathrm{mL}$ hydrocortisone hemisuccinate, $0.75 \mathrm{U} / \mathrm{mL}$ heparin sulfate, and $50 \mu \mathrm{g} / \mathrm{mL}$ ascorbic acid. MCF7 and C2C12 cells were cultured in DMEM medium supplemented with $10 \%$ FBS, $100 \mathrm{mU} / \mathrm{mL}$ penicillin and $100 \mu \mathrm{g} / \mathrm{mL}$ streptomycin.

\subsection{RT-PCR}

Total RNA was extracted from cells using TRIzol Reagent (Thermo Fisher Scientific), and the RNA was reverse transcribed using a high-capacity cDNA reverse transcription kit (Thermo Fisher Scientific) according to the manufacturer's protocol. PCR and quantitative PCR were performed with Takara Taq Hot Start Version (TaKaRa Biotechnology, Shiga, Japan) or Power SYBR Green PCR master mix (Thermo Fisher Scientific) as described previously [15]. Primer sequences are shown in Table 1. The relative mRNA expression was determined by the $2^{-\Delta \Delta C t}\left(2^{- \text {delta delta } C t}\right)$ method. HPRT was used as a housekeeping gene for normalization.

Table 1. Primer sequences used for RT-PCR.

\begin{tabular}{|c|c|c|c|c|}
\hline Species & Protein Name & Gene Name & Orientation & Sequence \\
\hline \multirow{22}{*}{ Human } & \multirow{2}{*}{ MCT1 } & \multirow{2}{*}{ SLC16A1 } & Forward & GGTGGAGGTCCTATCAGCAG \\
\hline & & & Reverse & TCAAGTTGAAGGCAAGCCCA \\
\hline & \multirow{2}{*}{ MCT4 } & \multirow{2}{*}{ SLC16A3 } & Forward & ATCCTGGGCTTCATTGACAT \\
\hline & & & Reverse & CTTCAGGAAATGCTCCACCT \\
\hline & \multirow{2}{*}{ SMCT1 } & \multirow{2}{*}{ SLC5A8 } & Forward & CGTCTCTGTGGAACAGTCCT \\
\hline & & & Reverse & TAAGACCACCCAGTGTGCAG \\
\hline & \multirow{2}{*}{ MCT5 } & \multirow{2}{*}{ SLC16A4 } & Forward & TCTACCCGGTTTGGGTTCTG \\
\hline & & & Reverse & GGGCTCCTGTCCAGTCATAC \\
\hline & \multirow{2}{*}{ MCT6 } & \multirow{2}{*}{ SLC16A5 } & Forward & CCTGAGATCATGTGCCAGTCT \\
\hline & & & Reverse & TAGGGCTATTCCAGCCCAGA \\
\hline & \multirow{2}{*}{ MCT7 } & \multirow{2}{*}{ SLC16A6 } & Forward & GGCATCATCTCTGGTCTGGG \\
\hline & & & Reverse & TGGTGCGAAAGCAAACACAG \\
\hline & \multirow{2}{*}{ МСТ9 } & \multirow{2}{*}{ SLC16A9 } & Forward & CACCCATCGTTGGTTGGTTT \\
\hline & & & Reverse & CTTGGGGAGTTGCTTGTTGC \\
\hline & \multirow{2}{*}{ MCT11 } & \multirow{2}{*}{ SLC16A11 } & Forward & GGTTTTCGGTGTACTCCCCG \\
\hline & & & Reverse & CTTAGGAAGCCTGACAGGGG \\
\hline & \multirow{2}{*}{ MCT12 } & \multirow{2}{*}{ SLC16A12 } & Forward & ACGGGCAGTCACAAGATGTAT \\
\hline & & & Reverse & CAACACTCCCAAGTGGAGCA \\
\hline & \multirow{2}{*}{ MCT13 } & \multirow{2}{*}{ SLC16A13 } & Forward & CAGTTTGGGAGCCCGGTAGG \\
\hline & & & Reverse & GAGCCTGACAGCAACCCAAT \\
\hline & \multirow{2}{*}{ MCT14 } & \multirow{2}{*}{ SLC16A14 } & Forward & GATAGTGGGCCCTTTCATCG \\
\hline & & & Reverse & CGTTTGCAGCATAGGCACTC \\
\hline
\end{tabular}


Table 1. Cont.

\begin{tabular}{|c|c|c|c|c|}
\hline Species & Protein Name & Gene Name & Orientation & Sequence \\
\hline & \multirow{2}{*}{ LAT1 } & \multirow{2}{*}{ SLC7A5 } & Forward & CCGTGCCGTCCCTCGTGTTC \\
\hline & & & Reverse & GGTTCACCTTGATGGGCCGCT \\
\hline & \multirow{2}{*}{ LAT2 } & \multirow{2}{*}{ SLC7A8 } & Forward & CAGAGTCTGGCCTTCGGCTC \\
\hline & & & Reverse & CCAGCCAGAAGTACTCTCCTTTG \\
\hline & \multirow{2}{*}{$4 \mathrm{~F} 2 \mathrm{HC}$} & \multirow{2}{*}{ SLC3A2 } & Forward & CTCGTGGTTCTCCACTCAGG \\
\hline & & & Reverse & CCG CAATCAAGAGCCTGTCT \\
\hline & \multirow{2}{*}{ ABCG2 } & & Forward & TCAGATGGGTTTCCAAGCGT \\
\hline & & & Reverse & AACCCCAGCTCTGTTCTGGA \\
\hline & \multirow{2}{*}{ MFSD2A } & & Forward & СTCCTGGCCATCATGCTCTC \\
\hline & & & Reverse & GGCCACCAAGATGAGAAA \\
\hline & \multirow{2}{*}{ MDM2 } & & Forward & AGGAGATTTGTTTGGCGTGC \\
\hline & & & Reverse & TGAGTCCGATGATTCCTGCTG \\
\hline & \multirow{2}{*}{$18 \mathrm{~S}$} & & Forward & CCCGTTGAACCCCATTCGT \\
\hline & & & Reverse & GССТСАСТАAАCCATCCAATCGGTA \\
\hline \multirow{16}{*}{ Mouse } & \multirow{2}{*}{ Mct5 } & \multirow{2}{*}{ Slc16a4 } & Forward & ACTCCGTTTCTCTGCAGGTC \\
\hline & & & Reverse & AGATCCCAAACCAGGTAGCA \\
\hline & \multirow{2}{*}{ Mct6 } & \multirow{2}{*}{ Slc16a5 } & Forward & TCGTGGTTTCCTTCCATCCTG \\
\hline & & & Reverse & CCCAGGCCTGTGATCACTCC \\
\hline & \multirow{2}{*}{ Mct7 } & \multirow{2}{*}{ Slc16a6 } & Forward & GGGGTAATCTCGGGTTTAGGG \\
\hline & & & Reverse & TGATAGCTGGTGCGAAAGCA \\
\hline & \multirow{2}{*}{ Mct9 } & \multirow{2}{*}{ Slc16a9 } & Forward & GAGCAGTCTTGCCCCCAATA \\
\hline & & & Reverse & ACCCACACTCGAACCTGTTG \\
\hline & \multirow{2}{*}{ Mct11 } & \multirow{2}{*}{ Slc16a11 } & Forward & TATGCCCCACTGGTTTTCGG \\
\hline & & & Reverse & TAGGAAGCCTGACAGAGGAGG \\
\hline & \multirow{2}{*}{ Mct12 } & \multirow{2}{*}{ Slc16a12 } & Forward & CGGGCAGTCACCAGATGTA \\
\hline & & & Reverse & ACTGACAACACTCCCAAGCG \\
\hline & \multirow{2}{*}{ Mct13 } & \multirow{2}{*}{ Slc16a13 } & Forward & GTTTGGGAGCCCAATAGGCAG \\
\hline & & & Reverse & CCTGACAGCAGCCCAATACT \\
\hline & \multirow{2}{*}{ Mct14 } & \multirow{2}{*}{ Slc16a14 } & Forward & TGATCGTGGGACCTTTCATCG \\
\hline & & & Reverse & GCAGGTAGGTAAGCCATCCC \\
\hline \multirow{2}{*}{ Human/Mouse } & \multirow{2}{*}{ HPRT } & & Forward & GCGTCGTGATTAGCGATGATGAAC \\
\hline & & & Reverse & ССТСССАТСТССТТСАТGACATCT \\
\hline
\end{tabular}

\section{4. siRNA Transfection}

hCMEC/D3 cells were seeded in 24-well culture plates at a density of $2 \times 10^{5}$ cells/well with culture medium. siRNAs for SLC16A1 (solute carrier gene family 16, member A1)/MCT1 (monocarboxylate transporter 1) (Silencer select siRNA, s579), SLC16A3/MCT4 (Silencer select siRNA, s17417), SLC16A4/MCT5 (Silencer select siRNA, s17413 and s17414), SLC16A6/MCT7 (Silencer select siRNA, s17407 and s17408), SLC16A13/MCT13 (Silencer select siRNA, s47339 and s47341) and negative control (Silencer select negative control siRNA) were obtained from Thermo Fisher Scientific. siRNAs were transfected using RNAiMax (Thermo Fisher Scientific) $24 \mathrm{~h}$ and $72 \mathrm{~h}$ after seeding. Each siRNA, diluted in Opti-MEM I Reduced Serum medium, and RNAiMax were mixed gently and incubated 
at room temperature for $20 \mathrm{~min}$. These mixtures were added to each well. The cells were incubated for a total of 4 days at $37^{\circ} \mathrm{C}$ under $5 \% \mathrm{CO}_{2}$ and then used for experiments.

\subsection{Uptake Measurements}

hCMEC/D3 cells were seeded in 24-well cell culture plates coated with Collagen type I at a density of $2.0 \times 10^{5}$ cells/well with culture medium. On the day of uptake measurement, the culture plates were kept in a water bath at $37{ }^{\circ} \mathrm{C}$. The medium was aspirated and washed with uptake buffers (for composition, see below). The uptake medium $(250 \mu \mathrm{L})$ containing radiolabeled L-lactate or radiolabeled HMB in indicated uptake buffers was added to the cells. Following incubation for indicated time periods, the medium was removed by aspiration and the cells were washed three times with ice-cold uptake buffer. The cells were then lysed in $1 \%$ sodium dodecyl sulfate/0.2 N NaOH and used for measurement of radioactivity. The $\mathrm{Na}^{+}$-containing buffer $(140 \mathrm{mM} \mathrm{NaCl}$, $5.4 \mathrm{mM} \mathrm{KCl}, 1.8 \mathrm{mM} \mathrm{CaCl}_{2}, 0.8 \mathrm{mM} \mathrm{MgSO}_{4}$, and $5 \mathrm{mM}$ D-glucose, $25 \mathrm{mM}$ Hepes/Tris ( $\mathrm{pH}$ 7.5)) was used to evaluate the $\mathrm{Na}^{+}$-dependent uptake. The $\mathrm{Na}^{+}$-free buffer (the same components except for the equimolar replacement of $\mathrm{NaCl}$ with $\mathrm{N}$-methyl-D-glucamine chloride ( $\mathrm{pH}$ 6)) was used to evaluate the $\mathrm{H}^{+}$-dependent uptake. The kinetic parameters of the uptake process were determined using the substrate concentration versus the uptake rate relationship according to the Michaelis-Menten equation describing a single saturable transport system. An Eadie-Hofstee plot was used as the linear transformation of the Michaelis-Menten equation to calculate the kinetic parameters.

In experiments related to inhibition of HMB uptake, the substrates of MCTs (lactate, pyruvate, acetate, propionate, butyrate, $\beta$-hydroxybutyrate, nicotinate and probenecid), organic anion transporters ( $p$-aminohippurate and probenecid), and amino acid transporters (glycine, proline, and leucine) were used. $\mathrm{NaCl}$ was added to the uptake buffer as an osmotic control while using some of these inhibitors at $20 \mathrm{mM}$.

\subsection{Intracellular $\mathrm{pH}\left(\mathrm{pH}_{\text {in }}\right)$ Measurements}

Cells were grown onto rectangular coverslips $(9 \times 22 \mathrm{~mm})$ until they reached confluency. Then, the cells were incubated with $7.5 \mu \mathrm{M}$ SNARF-1-AM in NaCl Buffer, $\mathrm{pH}$ 7.4 for $30 \mathrm{~min}$ at $37^{\circ} \mathrm{C}$, followed by $30 \mathrm{~min}$ incubation in dye-free buffer to ensure the complete hydrolysis of the ester and the leakage of uncleaved dye. Two coverslips were placed back to back in a holder perfusion device and perfused at a rate of $3 \mathrm{~mL} / \mathrm{min}$, and the fluorescence of SNARF-1 was monitored with a SLM-8100/DMX spectrofluorometer (Spectronics Instruments, Rochester, NY, USA) equipped for sample perfusion at $37^{\circ} \mathrm{C}$. The sample temperature was maintained at $37^{\circ} \mathrm{C}$ by keeping both the water jacket and perfusion buffer at $37^{\circ} \mathrm{C}$ using an iso-temperature immersion circulator water bath. All measurements were performed using $4 \mathrm{~nm}$ bandpass slits and an external rhodamine standard as a reference. Fluorescence was monitored in continuous-acquisition mode using an excitation wavelength of $534 \mathrm{~nm}$ and monitoring emissions at 584, 600, and $644 \mathrm{~nm}$. The fluorescence emission at $584 \mathrm{~nm}$ decreases, and that at $644 \mathrm{~nm}$ increases, respectively, with increasing $\mathrm{pH}$. The ratio of 644 to $584 \mathrm{~nm}$ was used to monitor $\mathrm{pH}$ changes. The $600 \mathrm{~nm}$ wavelength, which is insensitive to $\mathrm{pH}$, was used to evaluate the efficiency of dye loading, quenching, or other artifacts. Fluorescence data were converted to ASCII format for subsequent analyses using SigmaPlot.

For the in situ calibration of intracellular $\mathrm{pH}$, the cells attached to coverslips were perfused with High $\mathrm{K}^{+}$buffer $(10 \mathrm{mM} \mathrm{NaCl}, 146 \mathrm{mM} \mathrm{KCl}, 10 \mathrm{mM}$ HEPES, $10 \mathrm{mM} \mathrm{MES}$, $10 \mathrm{mM}$ Bicine, $2 \mu \mathrm{M}$ valinomycin, $6.8 \mu \mathrm{M}$ nigericin, $5 \mathrm{mM}$ glucose, $\mathrm{pH}$ 5.5-8.0, at intervals of $0.2 \mathrm{pH}$ unit). The buffer contained high $\mathrm{K}^{+}$to approximate the intracellular $\mathrm{K}^{+}$concentration. Nigericin is an ionophore that exchanges $\mathrm{H}^{+}$and $\mathrm{K}^{+}$across the membrane, rendering the $\mathrm{pH}_{\text {in }}$ equal to the extracellular $\mathrm{pH}\left(\mathrm{pH}_{\mathrm{ex}}\right)$. Valinomycin is an ionophore that moves $\mathrm{K}^{+}$across the plasma membrane and, together with nigericin, helps to equilibrate $\mathrm{pH}_{\text {in }}$ and $\mathrm{pH}_{\mathrm{ex}}$. The ratios $(r=644 / 584)$ of SNARF-1 were converted to $\mathrm{pH}$ using a modified Henderson-Hasselbalch equation [21]. The equation was solved using nonlinear least 
squares analysis with SigmaPlot to obtain the values of $\mathrm{p} K_{a}, R_{\min }$, and $R_{\max }$ for SNARF-1 in these cells. These parameters were used to convert ratio values to $\mathrm{pH}_{\mathrm{in}}$.

\subsection{Western Blot}

Whole-cell protein lysates were prepared from cells grown at 80-90\% confluency using RIPA lysis buffer with a protease-phosphatase inhibitor cocktail. The total protein contents of the samples were quantified using a BCA Protein Assay kit. Lysates were prepared at a final protein concentration of $1 \mathrm{mg} / \mathrm{mL}$, which also contained $\beta$-mercaptoethanol. Lysates were heated at $95{ }^{\circ} \mathrm{C}$ for $3 \mathrm{~min}$, and then separated by electrophoresis on SDS-PAGE and transferred to a Polyvinylidene difluoride membrane at $70 \mathrm{~V}$ for $2 \mathrm{~h}$ at $4{ }^{\circ} \mathrm{C}$. After transferal, the membranes were blocked with $5 \%$ milk or $5 \%$ bovine serum albumin (for phospho-protein) for $1 \mathrm{~h}$ and incubated with specific primary antibodies (Cell Signaling; p-mTOR; cat. no. 5536, mTOR; cat. no. 2983, p-p70S6K; cat. no. 9204, p70S6K; cat. no. 9202, Acetyl-Histone H3; cat. no. 9649, Histone H3; cat. no. 4499) overnight at $4{ }^{\circ} \mathrm{C}$ with gentle shaking. After incubation, the membranes were washed three times with TBST, $10 \mathrm{~min}$ each time, then incubated with HPR-conjugated secondary antibodies (cat. no. 1706515, Bio-Rad Laboratories, U.S.A.) for another hour, washed three times with TBST as before, and bands were visualized using Pierce ECL Western blotting substrate (Thermo Scientific; cat. no. 32106). The experiments were repeated thrice with three separate cell cultures and treatments, and densitometric scanning was used to quantify the signals.

\subsection{Statistics}

Uptake measurements were made in triplicate and the experiments were repeated twice with separate cultures. In all cases, data are expressed as means \pm S. D. Statistical differences between control groups and experimental groups were analyzed by paired Student's $t$ test or by one-way analysis of variance (ANOVA) followed by Dunnett's test for single and multiple comparisons; a $p<0.05$ was considered significant.

\section{Results}

\section{1. $H^{+}$-Coupled HMB Transport in hCMEC/D3 Cells}

In vitro studies with cloned transporters expressed heterologously in Xenopus laevis oocytes or mouse muscle cell line $\mathrm{C} 2 \mathrm{C} 12$ in culture have shown that HMB is a transportable substrate for the $\mathrm{Na}^{+}$-coupled monocarboxylate transporter SMCT1 (SLC5A8) and the $\mathrm{H}^{+}$-coupled monocarboxylate transporters MCT1 (SLC16A1) and MCT4 (SLC16A3) [15]. Therefore, we examined whether HMB is taken up into hCMEC/D3 cells by SMCT1 and/or MCTs. The uptake of HMB in these cells was found to be completely $\mathrm{Na}^{+}$-independent with no change in uptake when $\mathrm{NaCl}$ in the uptake buffer was replaced completely with $\mathrm{N}$-methyl-D-glucamine chloride (Figure 1A). However, in $\mathrm{Na}^{+}$-free buffer, reducing the $\mathrm{pH}$ from 7.5 to 6.0 markedly stimulated HMB uptake (Figure 1B), indicating the presence of a $\mathrm{H}^{+}$-coupled uptake mechanism. We then examined HMB uptake at different $\mathrm{pH}$ levels in a $\mathrm{Na}^{+}$-free buffer. The uptake showed robust dependence on the concentration of $\mathrm{H}^{+}$ in the uptake buffer; the uptake increased more than 10-fold when the $\mathrm{pH}$ was changed from 7 to 6. Since a previously published report implicated MCT1, MCT4, and SMCT1 in HMB uptake in muscle cells [15], we examined the expressions of these three transporters in hCMEC/D3 cells (Figure 1C). These studies provided evidence for the expression of MCT1 and MCT4, but not SMCT1, in these cells, thus corroborating the absence of a $\mathrm{Na}^{+}$-dependent uptake mechanism but the presence of $\mathrm{H}^{+}$-coupled uptake in these cells. 


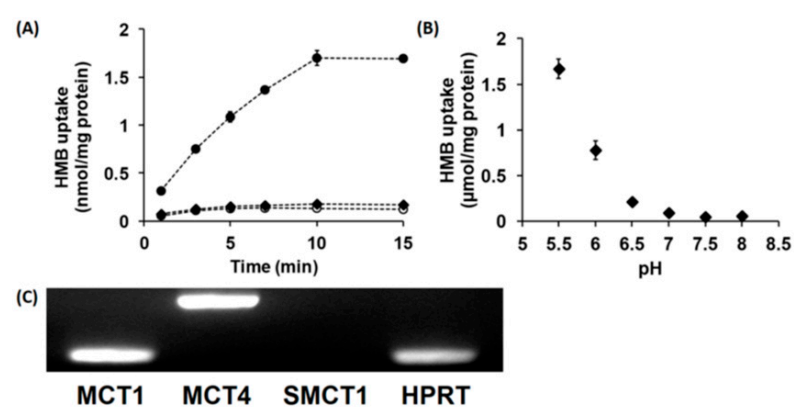

Figure 1. Time- and $\mathrm{pH}$-dependent uptake of $\mathrm{HMB}$ and mRNA expression of monocarboxylate transporters in hCMEC/D3 cells. (A) Uptake of $\left[{ }^{14} \mathrm{C}\right]-\mathrm{HMB}(15 \mu \mathrm{M})$ was measured for varying time periods in a $\mathrm{Na}^{+}$-free (NMDG chloride) buffer at $\mathrm{pH} 6.0(\bullet)$ or $7.5(\bigcirc)$ or $\mathrm{NaCl}$ buffer at $\mathrm{pH} 7.5(\bullet)$ (B) The uptake of $\left[{ }^{14} \mathrm{C}\right]-\mathrm{HMB}(30 \mu \mathrm{M})$ was measured for $3 \mathrm{~min}$ in a $\mathrm{Na}^{+}$-free buffer at $\mathrm{pH} 5.5-8.0$. (C) RT-PCR analysis of mRNAs for various monocarboxylate transporters in hCMEC/D3 cells using human-specific primers. HMB, $\beta$-hydroxy- $\beta$-methylbutyrate; NMDG, $N$-methyl-D-glucamine.

\subsection{Kinetics of HMB Uptake in hCMEC/D3 Cells}

We then examined the substrate saturation kinetics for HMB uptake in hCMEC/D3 cells. The uptake data fit best for a transport model involving a single carrier-mediated process and a non-saturable diffusion component. The theoretically calculated diffusional portion was subtracted from the total uptake to determine the portion of uptake that occurred solely via a carrier-mediated transport system. The data given in Figure $2 \mathrm{~A}$ show that HMB uptake in hCMEC/D3 cells was carrier-mediated and saturable. The linear transformation of the carrier-mediated component of HMB uptake (Eadie-Hofstee plot) was used to determine the values for the kinetic parameters (Figure 2B). The Michaelis constant $(\mathrm{Kt})$ for the uptake process was $3.8 \pm 0.7 \mathrm{mM}$ and the maximal velocity (Vmax) was $44.8 \pm 2.0 \mathrm{nmol} / \mathrm{mg}$ protein $/ \mathrm{min}$.
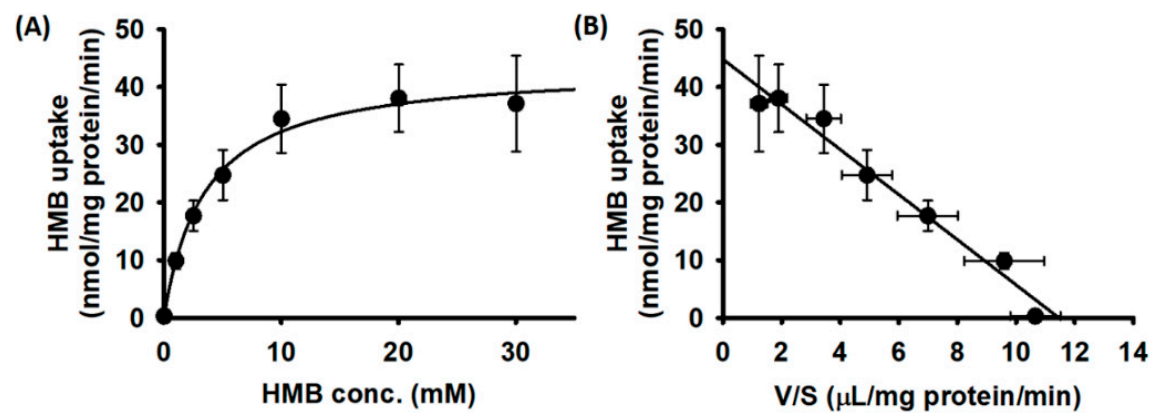

Figure 2. Saturation kinetics of HMB uptake in hCMEC/D3 cells. (A) $\left[{ }^{14} \mathrm{C}\right]-\mathrm{HMB}(30 \mu \mathrm{M})$ was used as a tracer to monitor HMB uptake and unlabeled $\mathrm{HMB}$ was used to alter HMB concentrations. Uptake measurements were made in a $\mathrm{Na}^{+}$-free buffer, $\mathrm{pH}$ 6. Data are presented as the HMB concentration (S) versus HMB uptake (V). (B) Eadie-Hofstee transformation of the same data (V versus V/S).

\subsection{Non-Involvement of OATs and PAT1 (SLC36A1) in HMB Uptake in hCMEC/D3 Cells}

$\mathrm{HMB}$ is a monocarboxylate and thus an anion; as such, it can potentially function as a substrate for the organic anion transporters (OATs), which transport anionic substrates without coupling to $\mathrm{H}^{+}$[22]. Therefore, we tested the effect of $p$-aminohippurate (PAH), the prototypical substrate for OATs, on the uptake of HMB in hCMEC/D3 cells. We found no effect (Table 2), indicating that HMB uptake in these cells does not involve OATs. In contrast to $\mathrm{PAH}$, the anion probenecid interacts with OATs as well as $\mathrm{H}^{+}$-coupled anion transporters, such as the members of the MCT/SLC16 family [23]. Based on this, we examined the effect of probenecid on HMB uptake. We found this organic anion to be an effective inhibitor of HMB uptake in hCMEC/D3 cells. PAT1 (proton-coupled amino acid transporter 1, SLC36A1) is another transporter, widely expressed in normal tissues, whose function is coupled to the transmembrane $\mathrm{H}^{+}$gradient $[24,25]$. Even though zwitterionic amino acids 
such as glycine and proline are the prototypical substrates for PAT1, short-chain fatty acids, such as acetate, propionate and butyrate, are recognized as substrates by this transporter; the transport mechanism is an electroneutral $\mathrm{H}^{+}$/anion cotransport [26]. This prompted us to examine the possible participation of PAT1 in HMB uptake in hCMEC/D3 cells by monitoring the effect of amino acid substrates of PAT1 on HMB uptake. We found little or no inhibition (Table 2), indicating the minimal involvement, if any, of PAT1 in HMB uptake in these cells.

Table 2. Inhibition of HMB uptake in hCMEC/D3 cells by various anions.

\begin{tabular}{|c|c|}
\hline Inhibitor & HMB Uptake (\% of Control) \\
\hline Control & $100 \pm 2$ \\
\hline $1 \mathrm{mM}$ PAH & $103 \pm 4$ \\
\hline 5 mM Glycine & $92.6 \pm 4.2$ \\
\hline $5 \mathrm{mM}$ Proline & $90.1 \pm 6.2 *$ \\
\hline $5 \mathrm{mM}$ Leucine & $81.4 \pm 5.2 * *$ \\
\hline Control (+20 mM Sodium chloride) & $100 \pm 2$ \\
\hline $20 \mathrm{mM}$ Lactate & $28.4 \pm 0.3^{* *}$ \\
\hline 20 mM Pyruvate & $23.2 \pm 1.5^{* *}$ \\
\hline $20 \mathrm{mM}$ Acetate & $29.1 \pm 1.1 * *$ \\
\hline $20 \mathrm{mM}$ Propionate & $26.7 \pm 1.0 * *$ \\
\hline $20 \mathrm{mM}$ Butyrate & $25.5 \pm 0.5^{* *}$ \\
\hline $20 \mathrm{mM} \beta$-Hydroxybutyrate & $22.2 \pm 0.9^{* *}$ \\
\hline $20 \mathrm{mM}$ Nicotinate & $27.5 \pm 2.8$ \\
\hline Control (+0.5\% DMSO) & $100 \pm 2$ \\
\hline $1 \mathrm{mM}$ Probenecid & $45.0 \pm 3.3^{* *}$ \\
\hline
\end{tabular}

Uptake of $\mathrm{HMB}(30 \mu \mathrm{M})$ in hCMEC/D3 cells was measured in a Na ${ }^{+}$-free buffer, $\mathrm{pH}$ 6.0, in the absence (control) or presence of various compounds at indicated concentrations. ${ }^{*}, p<0.05$ and ${ }^{* *}, p<0.01$ compared to the corresponding control uptake. PAH, $p$-aminohippurate; DMSO, dimethylsulfoxide; HMB, $\beta$-hydroxy- $\beta$-methylbutyrate.

\subsection{Substrate Selectivity of the Transport System Responsible for HMB Uptake in hCMEC/D3 Cells}

We monitored the substrate selectivity of the transport system that is responsible for HMB uptake in hCMEC/D3 cells by assessing the ability of other monocarboxylates to compete with HMB and inhibit its uptake. We found that all seven monocarboxylates tested in the present study caused marked inhibition of HMB uptake (Table 2). We already know that the transport system interacts with its monocarboxylate substrate HMB with low affinity, based on the Kt value in the low millimolar range. Accordingly, the other monocarboxylates examined in the study also interacted with the transport system with low affinity, as evident from the need for $20 \mathrm{mM}$ of these substrates to cause a $75 \%$ inhibition of HMB uptake.

\subsection{Relative Contribution of MCT1 and MCT4 to Total HMB Uptake in hCMEC/D3 Cells}

All of the known $\mathrm{H}^{+}$-coupled monocarboxylate transporters belong to the solute carrier gene family SLC16. This family has 14 members, but only 5 of them, namely, MCT1-4 and MCT7, have been shown to transport lactate and/or $\beta$-Hydroxybutyrate [16]. There are selective inhibitors for two of these transporters: SR13800 for MCT1 [27] and Bindarit for MCT4 [28]. With these inhibitors at concentrations that are expected to block the transport function of the respective MCTs completely, we assessed the contribution of MCT1 and MCT4 to the total uptake of HMB. The data from these experiments (Figure 3A) led to the conclusion that MCT1 contributes $~ 25 \%$ and MCT4 contributes $\sim 40 \%$ to HMB uptake in hCMEC/D3 cells. Comparable results were obtained for lactate uptake, except that the contribution by MCT4 was a little bit higher (Figure 3B). The conclusion from these studies is that, in addition to MCT1 and MCT4, there are other transporters that contribute to HMB uptake in BBB endothelial cells. 
(A)

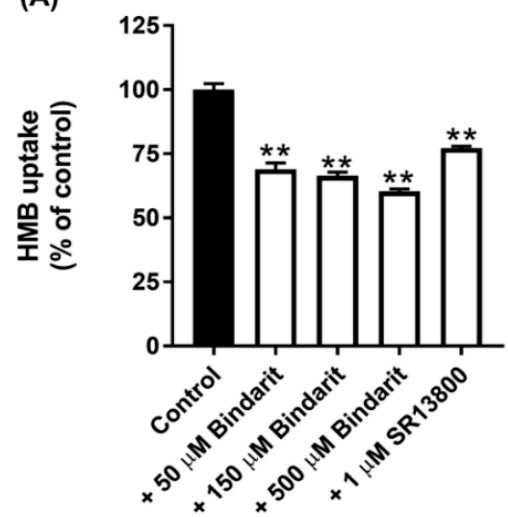

(B)

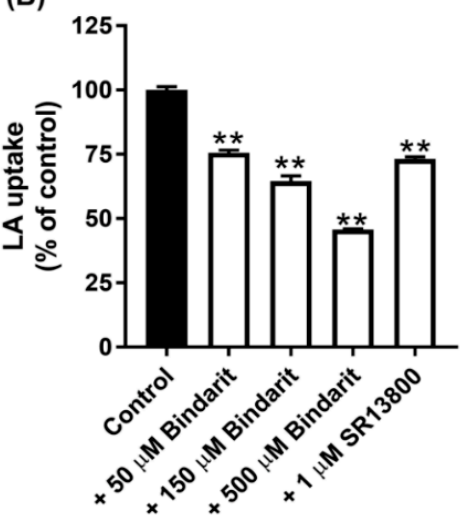

Figure 3. Effect of the MCT1-selective inhibitor SR13800 and MCT4-selective inhibitor Bindarit on the uptake of HMB and lactate in hCMEC/D3 cells. Uptake of HMB $(30 \mu \mathrm{M})(\mathbf{A})$ and lactate $(10 \mu \mathrm{M})(\mathbf{B})$ was measured in a $\mathrm{Na}^{+}$-free buffer, $\mathrm{pH}$ 6.0, using the respective radiolabeled compounds in the presence of SR13800 $(1 \mu \mathrm{M})$ or Bindarit $(50,150$, and $500 \mu \mathrm{M})$. ${ }^{* *} p<0.01$ compared to the corresponding control uptake measured in the absence of the inhibitor. HMB, $\beta$-hydroxy- $\beta$ methylbutyrate; LA, lactic acid.

\subsection{Expression Profile of Lactate Transporters and Orphan Transporters in SLC16 Family in hCMEC/D3 Cells}

Of the 14 members of the SLC16 family, MCT6, MCT8, MCT9 and MCT10 transport substrates structurally unrelated to the small monocarboxylates such as lactate and $\beta$ hydroxybutyrate [16]. As the substrate specificity of these four SLC16 family members is known, it is unlikely that any of these transporters mediate HMB uptake. Human MCT2 transports pyruvate but not lactate [16]. MCT3 shows a restricted expression pattern, primarily found in retinal pigment epithelium [29]. To predict which of the members of the SLC16 family, other than MCT1 and MCT4, could contribute to HMB uptake in hCMEC/D3 cells, we performed RT-PCR to determine the expression profile of potential candidates for HMB uptake. For comparison, we also examined the expression profiles in the human breast cancer cell line MCF7 and the mouse skeletal muscle cell line $\mathrm{C} 2 \mathrm{C} 12$, both of which exhibit robust $\mathrm{H}^{+}$-coupled HMB uptake [15]. These studies showed high expressions of MCT5, MCT6, MCT7, MCT12, MCT13, and MCT14 in hCMEC/D3 cells (Figure 4A). The transporters whose expressions were common among the three cell lines that are positive for HMB transport were MCT5, MCT7, and MCT13 (Figure 4A-C).

(A) hCMEC/D3

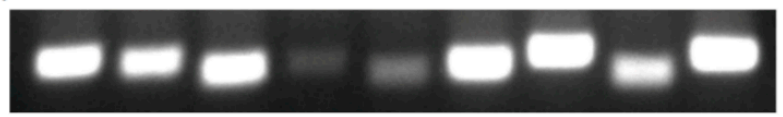

MCT5 MCT6 MCT7 MCT9 MCT11 MCT12 MCT13 MCT14 HPRT

(B) MCF7

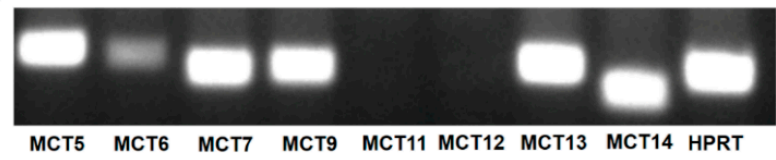

(C) $\mathrm{C2C} 12$

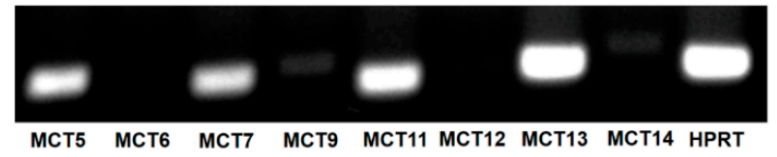

Figure 4. Expression of monocarboxylate transporters in hCMEC/D3 cells (A), MCF7 cells (B) and C2C12 cells (C). RT-PCR analysis of mRNAs for various monocarboxylate transporters was performed using human-specific primers (hCMEC/D3 and MCF7) or mouse-specific primers (C2C12). 
MCT7 has been shown to be a transporter specifically for $\beta$-hydroxybutyrate [30], while the other two are orphan transporters with no established transport function [16]. As there are no specific inhibitors available for these three transporters, we decided to suppress their expression by siRNA, and then examine HMB uptake to determine if any of these three transporters contributes to HMB uptake in hCMEC/D3 cells. The siRNAs examined in the study did lead to marked reductions in the mRNA levels of the corresponding transporter, but HMB uptake remained unaffected (Figure 5), leading to the conclusion that none of these three transporters make any significant contribution to HMB uptake in hCMEC/D3 cells. In contrast, the siRNA-mediated down-regulation of MCT1 and MCT4 did reduce HMB uptake, corroborating the data from the previous experiments that implicated these two transporters in HMB uptake.

(A)

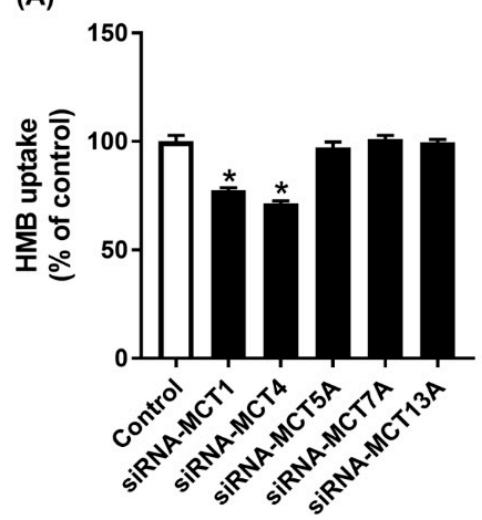

(B)

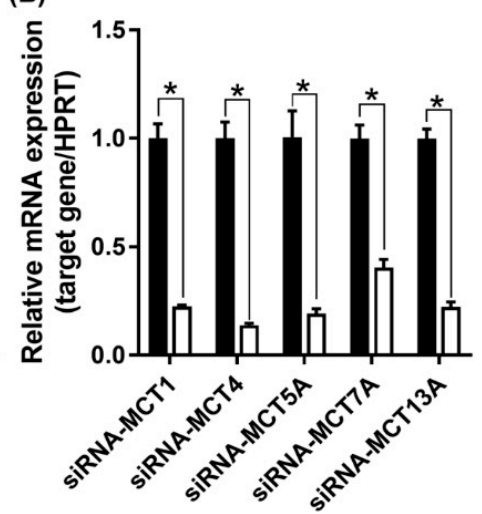

Figure 5. Effect of siRNA-mediated knockdown of MCT transporters on HMB uptake in hCMEC/D3 cells. (A) Uptake of HMB $(30 \mu \mathrm{M})$ in hCMEC/D3 cells treated with MCT transporter-siRNAs was measured in the absence of $\mathrm{Na}^{+}$(NMDG chloride buffer) at pH 6.0. (B) mRNA expression of MCT transporters in hCMEC/D3 cells treated with MCT transporter-siRNAs was evaluated by quantitative-RT-PCR. ${ }^{*} p<0.05$ compared to corresponding control cells treated with an empty vector in a similar manner (black bars).

\subsection{Evidence for Coupled Transport of HMB and $\mathrm{H}^{+}$in $h \mathrm{CMEC/D} 3$ Cells}

$\mathrm{HMB}$ transport in hCMEC/D3 cells is stimulated by extracellular acidic $\mathrm{pH}$, indicating the potential coupled transport of $\mathrm{HMB}$ with $\mathrm{H}^{+}$. To confirm this mode of $\mathrm{HMB}$ transport, we monitored intracellular $\mathrm{pH}$ in these cells in the presence of $\mathrm{HMB}$ in a $\mathrm{Na}^{+}$-free medium, with lactate and $\beta$-hydroxybutyrate as positive controls for $\mathrm{H}^{+}$-coupled transport. When the cells were switched to $\mathrm{Na}^{+}$-free perfusion medium, intracellular $\mathrm{pH}$ decreased, indicating cellular acidification (Figure 6). This is because of the transport function of the $\mathrm{Na}^{+} / \mathrm{H}^{+}$ exchanger working in the reverse direction (i.e., $\mathrm{Na}^{+}$efflux coupled to $\mathrm{H}^{+}$influx). When lactate, $\beta$-hydroxybutyrate or $\mathrm{HMB}$ was added to the $\mathrm{Na}^{+}$-free buffer, cellular acidification increased. The magnitude of intracellular acidification was similar for all three monocarboxylates when each was used at $10 \mathrm{mM}$. These data provide conclusive evidence of the $\mathrm{H}^{+}$-coupled transport of $\mathrm{HMB}$ in these cells.

3.8. Influence of HMB on the Expression of Selective Transporters in hCMEC/D3 Cells and Relevance of mTOR Signaling and HDAC Inhibition to the Process

HMB is a signaling molecule with an ability to activate the mTOR pathway [4-6], which controls the expression of the oncogene c-Myc. There is evidence for the induction of the amino acid transporter LAT1 (SLC7A5) by c-Myc [31]. Since LAT1 is the primary amino acid transporter in the blood-brain barrier [32] and its deficiency is associated with decreased levels of specific amino acids (branched-chain amino acids, including leucine) in the brain in the pathogenesis of autism spectrum disorder [33,34], we raised the question as to whether HMB has the ability to enhance the expression of LAT1 in hCMEC/D3 cells. 
A
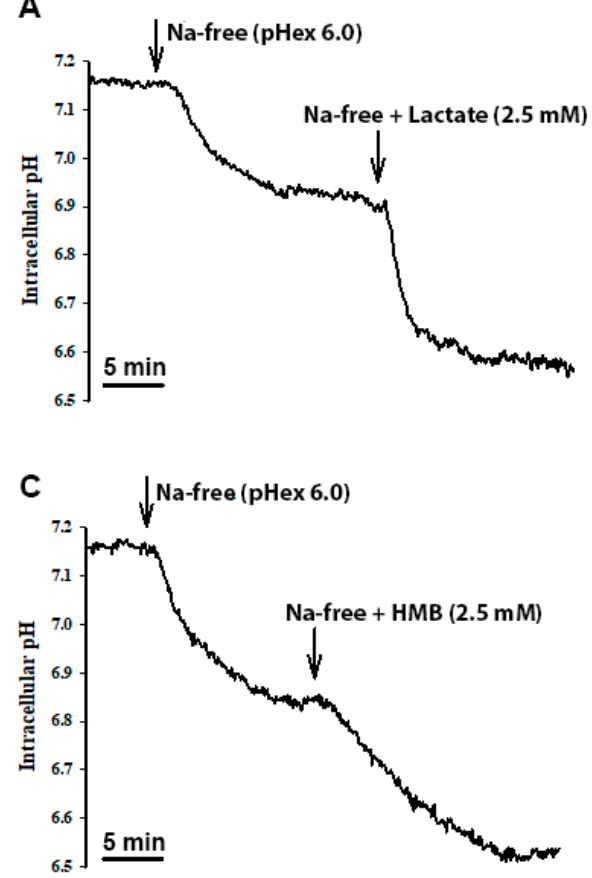

B
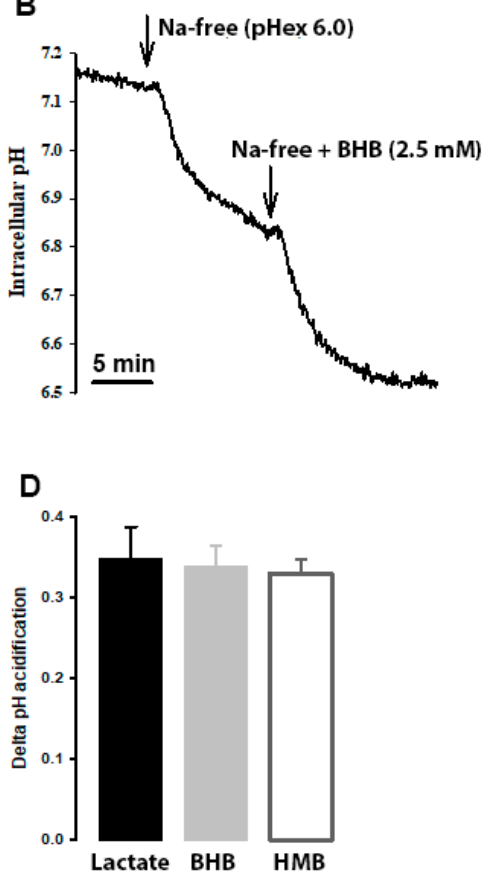

Figure 6. Cells were perfused with $\mathrm{Na}^{+}$-containing buffer $\left(\mathrm{pH}_{\mathrm{ex}} 7.4\right)$ until a steady-state $\mathrm{pH}_{\text {in }}$ was reached. Then, the perfusate was switched to $\mathrm{Na}^{+}$-free $\left(\mathrm{pH}_{\mathrm{ex}} 6.0\right.$; arrow), which resulted in a slow acidification of the cell. When the intracellular $\mathrm{pH}$ reached a steady state, the perfusate was switched to either (A) lactate, (B) $\beta$-hydroxybutyrate $(\mathrm{OH}$-butyrate) or (C) $\beta$-hydroxy- $\beta$-methylbutyrate (HMB) in $\mathrm{Na}^{+}$free buffer $\left(\mathrm{pH}_{\mathrm{ex}}\right.$ 6.0; arrow). In all three cases, a further acidification was observed. The scale bar, in each graph, represents $5 \mathrm{~min}$. The graph bar (D) represents the $\Delta \mathrm{pH}_{\text {in }}$ acidification from the $\mathrm{Na}^{+}$-free buffer $\left(\mathrm{pH}_{\mathrm{ex}} 6.0\right)$ to either lactate, $\mathrm{OH}$-butyrate or $\mathrm{HMB}$ in $\mathrm{Na}^{+}$free buffer $\left(\mathrm{pH}_{\mathrm{ex}} 6.0\right)$. Each treatment was repeated three times. The graph represents the mean $\pm \mathrm{SEM}$.

To address this question, we treated the cells with $2 \mathrm{mM} \mathrm{HMB}$ for $16 \mathrm{~h}$ and then prepared RNA and cell lysates. In parallel, we also examined the effects of butyrate $(2 \mathrm{mM})$, a structurally related molecule that is also a signaling molecule but works primarily via the inhibition of class I histone deacetylases, using a similar experimental strategy. Using the RNA from the control and the treated cells, we monitored the expression of mRNAs for nine different transporters by RT-PCR (Figure 7A) and real-time qRT-PCR (Figure 7B). The group of transporters we selected for this study included those involved in the cellular uptake of monocarboxylates, including HMB and butyrate [35] and branched-chain amino acids. Among the nine transporters examined, HMB treatment increased the expression of only SLC7A5. In contrast, butyrate induced the expression of a majority of them. We also monitored the expression of MDM2, an E3 ubiquitin-protein ligase, whose expression runs in parallel with the inhibition of histone deacetylases. MDM2 expression was not altered in HMB-treated cells but was reduced in butyrate-treated cells. This shows that under the conditions and concentrations employed in this experiment, butyrate causes the inhibition of histone deacetylases, but HMB does not. We further probed this differential activation of two different signaling pathways by HMB and butyrate. This was done using the protein lysates prepared from control and treated cells to monitor the acetylation status of histone $\mathrm{H} 3$ and the phosphorylation status of mTOR and its downstream target S6 kinase. Butyrate treatment clearly increased the acetylation of histone H3, whereas HMB did not (Figure 7C). In contrast, HMB showed evidence of mTOR activation, as evident from the increased phosphorylation of S6 kinase, even though we could not find any increase in the phosphorylation of mTOR. Butyrate also increased the phosphorylation of mTOR and S6 kinase, but its effect on histone acetylation status was much more robust. These data show that HMB primarily activates the mTOR pathway with little effect on histone deacetylases. 

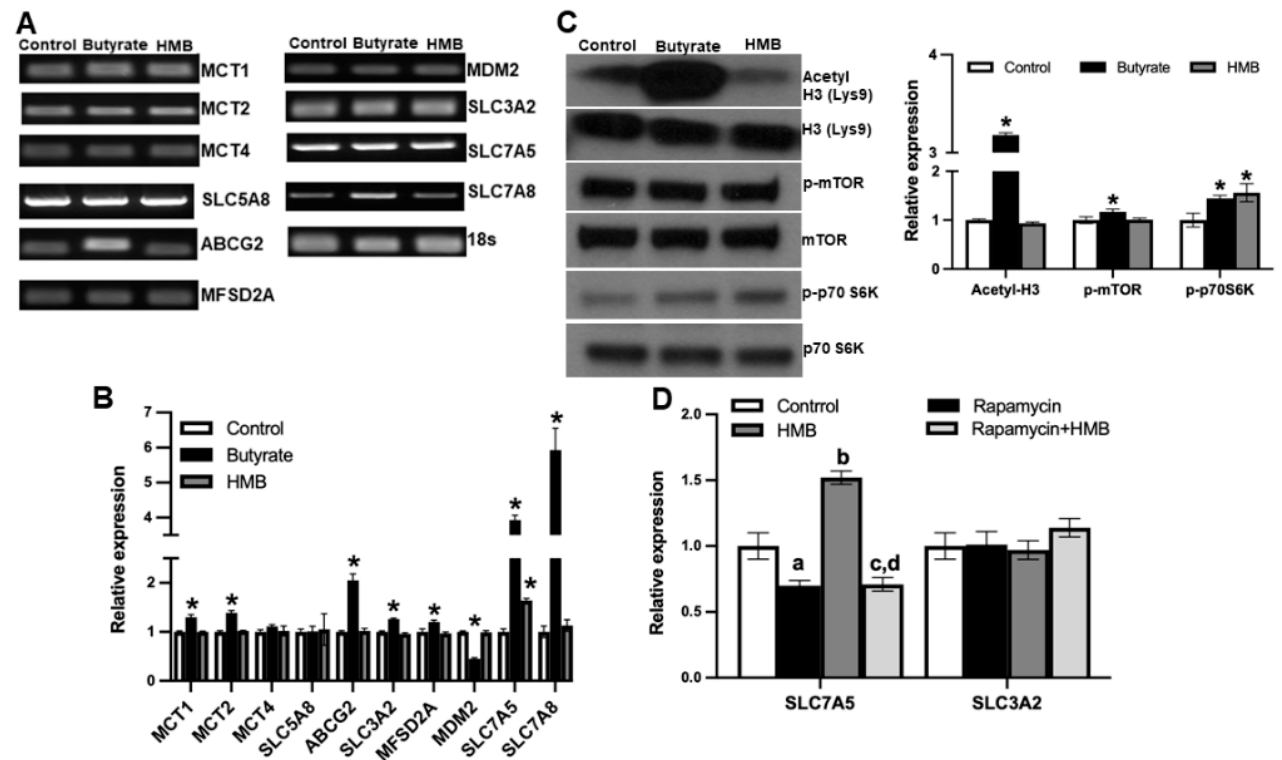

Figure 7. hCMEC/D3 cells were treated with $2 \mathrm{mM}$ of butyrate and $2 \mathrm{mM}$ of HMB for $16 \mathrm{~h}$. (A) Gene expression assessed by RT-PCR (A), gene expression by quantitative PCR (B), and (C) Western blot assessment of the total and phospho-form of mTOR and S6 kinase, and also for the total and acetylated form of histone H3 (C). hCMEC/D3 cells were treated with rapamycin $(10 \mu \mathrm{M})$ or HMB (2 mM) alone or in combination for $24 \mathrm{~h}$, and RNA prepared from control and treated cells was used to monitor the expression of SLC7A5 and its subunit SLC3A2 (D). Data are represented as mean \pm SEM for three independent experiments. ${ }^{*} p<0.05$. In Figure 7D, a, significantly different from control $(p<0.05)$; $\mathbf{b}$, significantly different from control $(p<0.05)$; $c$, significantly different from HMB treatment alone $(p<0.05) ; \mathrm{d}$, not different from rapamycin alone $(p>0.05)$.

Next, we wanted to determine whether the activation of mTOR was involved in the HMB-mediated induction of the amino acid transporter SLC7A5. Since SLC7A5 heterodimerizes with SLC3A2 to function as an amino acid transporter, we also examined its expression. We used rapamycin, an inhibitor of the mTOR signaling pathway, to establish the involvement of mTOR activation in the HMB-dependent induction of SLC7A5. Treatment with rapamycin slightly decreased the expression of SLC7A5, but more importantly, the HMB-mediated induction of SLC7A5 was blocked completely by the presence of rapamycin (Figure 7D). The effect of HMB was specific to SLC7A5, with no effect on the expression of SLC3A2. These findings lead to the conclusion that the treatment of hCMEC/D3 cells with HMB induces SLC7A5 in association with the activation of mTOR and its downstream targets, but with no involvement of histone deacetylases.

\section{Discussion}

This represents the first study to investigate the uptake of the nutritional ingredient $\beta$-hydroxy- $\beta$-methylbutyrate (HMB) in blood-brain barrier endothelial cells. The data support the conclusion that the blood-brain barrier has the necessary transport mechanism for the transfer of HMB from systemic circulation into the brain. Previously published studies have shown that orally administered HMB has biological effects on brain function, clearly indicating the accessibility of circulating HMB by the brain [4-6,12-14]. In the present study, we investigated the transport mechanisms for HMB uptake in blood-brain barrier endothelial cells. These studies have demonstrated that the HMB is taken up by these cells actively, driven by a $\mathrm{Na}^{+}$-independent, but $\mathrm{H}^{+}$-coupled, transport process. The characteristics of the transport process indicate the predominant contribution of the MCT transporters belonging to the SLC16 family to the uptake process. With specific inhibitors, we were able to demonstrate the involvement of MCT1 and MCT4, but the combined contribution by these two transporters amounts only to $\sim 60 \%$ of total uptake. 
This indicates that there are additional transporters, not yet identified at the molecular level, in the blood-brain barrier that mediate HMB uptake.

The hCMEC/D3 cell line is an established in vitro model for the blood-brain barrier, as this cell line expresses normal endothelial markers CD31, VE cadherin, and von Willebrand factor, forms monolayers in culture, and responds positively to endothelial growth factors [36,37]. Proteomic analyses of this cell line have provided evidence for the expression of MCT1 [38]. The data on MCT4 expression in the blood-brain barrier's endothelial cells are scarce, and some studies have concluded that MCT4 is not expressed in the blood-brain barrier [39]. In the present study, we found the robust expression of MCT4 in hCMEC/D3 cell line, both at the mRNA level and at the functional level (Bindarit-sensitive uptake). Even though MCT1 and MCT4 are both capable of bidirectional transport, the transport features and substrate affinities have led to the conclusion that MCT1 functions mostly in the influx of its substrates, whereas MCT4 functions in the efflux of its substrates [40,41]. The endothelial cell layer forming the blood-brain barrier is a polarized structure with distinct luminal and abluminal membrane components. The location of MCT1 in the luminal membrane of the blood-brain barrier is known [42], but the molecular identity of the transporter that mediates the efflux of monocarboxylates on the brain side has not been established. MCT4 might fulfill this function in native blood-brain barrier endothelial cells, but this needs to be investigated. It cannot be ruled out, however, that MCT1 functions both in the influx across the luminal membrane and in the efflux across the abluminal membrane of the endothelial cells in this barrier structure. Additional studies are needed to address these issues.

Skeletal muscle is the most predominant tissue target for $\mathrm{HMB}$ as a nutritional ingredient. HMB elicits robust anabolic activity in this tissue by promoting protein synthesis mediated by the activation of the mTOR signaling pathway. Since the mTOR pathway is ubiquitous in mammalian tissues, the HMB-mediated activation of this signaling pathway might have biological relevance in blood-brain barrier endothelial cells. With this rationale, we examined the effect of $\mathrm{HMB}$ on the phosphorylation status of mTOR and its downstream target $\mathrm{S} 6$ kinase in hCMEC/D3 cells. We found evidence of mTOR activation. Since butyrate and $\beta$-hydroxybutyrate, two of the endogenous molecules that are structurally similar to $\mathrm{HMB}$, are known inhibitors of histone deacetylases $[8,9,43]$, we investigated the effect of HMB on the acetylation status of histone H3. There was no change in this parameter, suggesting that HMB does not function as an inhibitor of histone deacetylases, at least at the concentration $(2 \mathrm{mM})$ used in the study. Under identical conditions, butyrate showed a robust increase in the acetylation of $\mathrm{H} 3$, serving as a positive control for the inhibition of histone deacetylases. We then compared the expressions of selective transporters in control and HMB-treated cells to determine whether the observed mTOR activation has any influence on nutrient transporters, particularly those involved in the transport of monocarboxylates, such as lactate, butyrate, $\beta$-hydroxybutyrate, and HMB. There was no effect on the expression of MCTs and SMCT1, nor on the expression of ABCG2, which is known to function as an efflux transporter for monocarboxylates such as butyrate [44]. Then, we examined the expression of SLC7A5 and SLC7A8, two of the amino acid transporters that transport branched-chain amino acids such as leucine. We selected these two transporters solely because leucine is the source of endogenous HMB and SLC7A5 is a known target for mTOR. We found a significant increase in the expression of SLC7A5, but not SLC7A8, in HMB-treated cells. To confirm that the induction of SLC7A5 by HMB involves mTOR signaling, we evaluated the effect of rapamycin, a potent inhibitor of the mTOR pathway. In the presence of this inhibitor, the HMB-mediated increase in SLC7A5 expression was completely blocked. These data show convincingly that the activation of mTOR by HMB is responsible for the observed increase in SLC7A5 expression in these cells. In contrast, butyrate induced the expression of not only SLC7A5, but also SLC7A8, most likely involving the inhibition of histone deacetylases in the process. This finding that HMB induces SLC7A5 expression in the blood-brain barrier's endothelial cells may have significance because deficiencies in this particular transporter contribute to the pathogenesis of autism 
spectrum disorder. Mutations in SLC7A5 that lead to the partial loss of transport activity have been found in patients with autism spectrum disorder, associated with a decrease in the brain levels of branched-chain amino acids [33,34]. Since our studies have found that $\mathrm{HMB}$ increases the expression of this transporter in the blood-brain barrier, it raises the possibility that HMB as a nutritional ingredient might have therapeutic benefits in patients affected with this disorder.

Author Contributions: Conceptualization, V.G., K.H. and S.L.P.; methodology, K.H., S.S., S.R.S. and J.O.; data analysis, Y.D.B.; writing — original draft preparation, V.G.; writing-review and editing, Y.D.B., R.R., S.L.P.; funding acquisition, S.L.P., R.R. All authors have read and agreed to the published version of the manuscript.

Funding: This research was co-funded by a research grant from the Abbott Nutrition, and the Welch Endowed Chair in Biochemistry, Grant No. BI-0028, at Texas Tech University Health Sciences Center.

Institutional Review Board Statement: Not applicable.

Informed Consent Statement: Not applicable.

Data Availability Statement: All the data relevant to the studies are provided in the manuscript.

Conflicts of Interest: S.L.P. and R.R. are employees of Abbott. The other authors declare no conflict of interest. S.L.P. and R.R. had no role in the design of the study, in the collection, analyses, or interpretation of data, or in the decision to publish the results.

\section{References}

1. Blair, M.C.; Neinast, M.D.; Arany, Z. Whole-body metabolic fate of branched-chain amino acids. Biochem. J. 2021, 478, 765-776. [CrossRef]

2. Nie, C.; He, T.; Zhang, W.; Zhang, G.; Ma, X. Branched chain amino acids: Beyond nutrition metabolism. Int. J. Mol. Sci. 2018, 19, 954. [CrossRef] [PubMed]

3. Le Couteur, D.G.; Solon-Biet, S.M.; Cogger, V.C.; Ribeiro, R.; de Cabo, R.; Raubenheimer, D.; Cooney, G.J.; Simpson, S.J. Branched chain amino acids, aging and age-related health. Ageing Res. Rev. 2020, 64, 101198. [CrossRef] [PubMed]

4. Pimentel, G.D.; Rosa, J.C.; Lira, F.S.; Zanchi, N.E.; Ropelle, E.R.; Oyama, L.M.; Oller do Nascimento, C.M.; de Mello, M.T.; Tufik, S.; Santos, R.V.T. $\beta$-Hydroxy- $\beta$-methylbutyrate $(\mathrm{HM} \beta)$ supplementation stimulates skeletal muscle hypertrophy in rats via the mTOR pathway. Nutr. Metab. (Lond.) 2011, 8, 11. [CrossRef] [PubMed]

5. Kimura, K.; Cheng, X.W.; Inoue, A.; Hu, L.; Koike, T.; Kuzuya, M. $\beta$-Hydroxy- $\beta$-methylbutyrate facilitates PI3K/Akt-dependent mammalian target of rapamycin and FoxO1/3a phosphorylations and alleviates tumor necrosis factor $\alpha /$ interferon $\gamma$-induced MuRF-1 expression in C2C12 cells. Nutr. Res. 2014, 34, 368-374. [CrossRef]

6. Kaczka, P.; Michalczyk, M.M.; Jastrzab, R.; Gawelczyk, M.; Kubicka, K. Mechanism of action and the effect of $\beta$-hydroxy- $\beta$ methylbutyrate (HMB) supplementation on different types of physical performance-A systematic review. J. Hum. Kinet. 2019, 68, 211-222. [CrossRef] [PubMed]

7. Duan, Y.; Zhong, Y.; Xiao, H.; Zheng, C.; Song, B.; Wang, W.; Guo, Q.; Li, Y.; Han, H.; Gao, J.; et al. Gut microbiota mediates the protective effects of dietary $\beta$-Hydroxy- $\beta$-methylbutyrate (HMB) against obesity induced by high-fat diets. FASEB J. 2019, 33, 10019-10033. [CrossRef]

8. Thangaraju, M.; Gopal, E.; Martin, P.M.; Ananth, S.; Smith, S.B.; Prasad, P.D.; Sterneck, E.; Ganapathy, V. SLC5A8 triggers tumor cell apoptosis through pyruvate-dependent inhibition of histone deacetylases. Cancer Res. 2006, 66, 11560-11564. [CrossRef] [PubMed]

9. Singh, N.; Thangaraju, M.; Prasad, P.D.; Martin, P.M.; Lambert, N.A.; Boettger, T.; Offermanns, S.; Ganapathy, V. Blockade of dendritic cell development by bacterial fermentation products butyrate and propionate through a transporter (Slc5a8)-dependent inhibition of histone deacetylases. J. Biol. Chem. 2010, 285, 27601-27608. [CrossRef]

10. Ganapathy, V.; Thangaraju, M.; Prasad, P.D.; Martin, P.M.; Singh, N. Transporters and receptors for short-chain fatty acids as the molecular link between colonic bacteria and the host. Curr. Opin. Pharmacol. 2013, 13, 869-874. [CrossRef] [PubMed]

11. Sivaprakasam, S.; Bhutia, Y.D.; Ramachandran, S.; Ganapathy, V. Cell-surface and nuclear receptors in the colon as targets for bacterial metabolites and its relevance to colon health. Nutrients 2017, 9, 856. [CrossRef]

12. Saito, R.; Vilchez, J.D.; Giron, M.D.; Cabrera, E.; Campos, N.; Manzano, M.; Rueda, R.; Lopez-Pedrosa, J.M. $\beta$-Hydroxy- $\beta$ methylbutyrate (HMB) promotes neurite outgrowth in Neuro2a cells. PLoS ONE 2015, 10, e0135614.

13. Kougias, D.G.; Nolan, S.O.; Koss, W.A.; Kim, T.; Hankosky, E.R.; Gulley, J.M.; Juraska, J.M. $\beta$-Hydroxy- $\beta$-methylbutyrate ameliorates aging effects in the dendritic tree of pyramidal neurons in the medial prefrontal cortex of both male and female rats. Neurobiol. Aging 2016, 40, 78-85. [CrossRef] [PubMed]

14. Kougias, D.G.; Hankosky, E.R.; Gulley, J.M.; Juraska, J.M. $\beta$-Hydroxy- $\beta$-methylbutyrate (HMB) ameliorates age-related deficits in water maze performance, especially in male rats. Physiol. Behav. 2017, 170, 93-99. [CrossRef] [PubMed] 
15. Ogura, J.; Sato, T.; Higuchi, K.; Bhutia, Y.D.; Babu, E.; Masuda, M.; Miyauchi, S.; Rueda, R.; Pereira, S.L.; Ganapathy, V. Transport mechanisms for the nutritional supplement $\beta$-hydroxy- $\beta$-methylbutyrate (HMB) in mammalian cells. Pharm. Res. 2019, 36, 84. [CrossRef] [PubMed]

16. Felmlee, M.A.; Jones, R.S.; Rodriguez-Cruz, V.; Follman, K.E.; Morris, M.E. Monocarboxylate transporters (SLC16): Function, regulation, and role in health and disease. Pharmacol. Rev. 2020, 72, 466-485. [CrossRef]

17. Halestrap, A.P. The SLC16 gene family-Structure, role and regulation in health and disease. Mol. Aspects Med. 2013, 34, 337-349. [CrossRef]

18. Uchida, Y.; Ohtsuki, S.; Katsukura, Y.; Ikeda, C.; Suzuki, T.; Kamiie, J.; Terasaki, T. Quantitative targeted absolute proteomics of human blood-brain transporters and receptors. J. Neurochem. 2011, 117, 333-345. [CrossRef]

19. Lauritzen, F.; Eid, T.; Bergersen, L.H. Monocarboxylate transporters in temporal lobe epilepsy: Roles of lactate and ketogenic diet. Brain Struct. Funct. 2015, 220, 1-12. [CrossRef] [PubMed]

20. Perez-Escuredo, J.; Van Hee, V.F.; Sboarina, M.; Falces, J.; Payen, V.L.; Pellerin, L.; Sonveaux, P. Monocarboxylate transporters in the brain and in cancer. Biochim. Biophys. Acta 2016, 1863, 2481-2497. [CrossRef]

21. Rojas, J.D.; Sennoune, S.R.; Maiti, D.; Bakunts, K.; Reuveni, M.; Sanka, S.C.; Martinez, G.M.; Seftor, E.A.; Meininger, C.J.; Wu, G.; et al. Vacuolar type $\mathrm{H}^{+}$-ATPases at the plasma membrane regulate $\mathrm{pH}$ and cell migration in microvascular endothelial cells. Am. J. Physiol. Heart Circ. Physiol. 2006, 291, H11478-H1157. [CrossRef]

22. Nigam, S.K.; Bush, K.T.; Martovetsky, G.; Ahn, S.Y.; Liu, H.C.; Richard, E.; Bhatnagar, V.; Wu, W. The organic anion transporter (OAT) family: A systems biology perspective. Physiol. Rev. 2015, 95, 83-123. [CrossRef]

23. Okamura, A.; Emoto, A.; Koyabu, N.; Ohtani, H.; Sawada, Y. Transport and uptake of nateglinide in Caco-2 cells and its inhibitory effect on human monocarboxylate transporter MCT1. Br. J. Pharmacol. 2002, 137, 391-399. [CrossRef]

24. Chen, Z.; Fei, Y.J.; Anderson, C.M.H.; Wake, K.A.; Miyauchi, S.; Huang, W.; Thwaites, D.T.; Ganapathy, V. Structure, function and immunolocalization of a proton-coupled amino acid transporter (hPAT1) in the human intestinal cell line Caco-2. J. Physiol. 2003, 546, 349-361. [CrossRef] [PubMed]

25. Thwaites, D.T.; Anderson, C.M.H. The SLC36 family of proton-coupled amino acid transporters and their potential role in drug transport. Br. J. Pharmacol. 2011, 164, 1802-1816. [CrossRef]

26. Foltz, M.; Boll, M.; Raschka, L.; Kottra, G.; Daniel, H. A novel bifunctionality: PAT1 and PAT2 mediate electrogenic proton/amino acid and electroneutral proton/fatty acid symport. FASEB J. 2004, 18, 1758-1760. [CrossRef]

27. Doherty, J.R.; Yang, C.; Scott, K.E.; Cameron, M.D.; Fallahi, M.; Li, W.; Hall, M.A.; Amelio, A.L.; Mishra, J.K.; Li, F.; et al. Blocking lactate export by inhibiting the Myc target MCT1 disables glycolysis and glutathione synthesis. Cancer Res. 2014, 74, 908-920 [CrossRef] [PubMed]

28. Futagi, Y.; Kobayashi, M.; Narumi, K.; Furugen, A.; Iseki, K. Identification of a selective inhibitor of human monocarboxylate transporter 4. Biochem. Biophys. Res. Commun. 2018, 495, 427-432. [CrossRef]

29. Yoon, H.; Fanelli, A.; Grollman, E.F.; Philp, N.J. Identification of a unique monocarboxylate transporter (MCT3) in retinal pigment epithelium. Biochem. Biophys. Res. Commun. 1997, 234, 90-94. [CrossRef] [PubMed]

30. Hugo, S.E.; Cruz-Garcia, L.; Karanth, S.; Anderson, R.M.; Stainier, D.Y.; Schlegel, A. A monocarboxylate transporter required for hepatocyte secretion of ketone bodies during fasting. Genes Dev. 2012, 26, 282-293. [CrossRef] [PubMed]

31. Venkateswaran, N.; Lafita-Navarro, M.C.; Hao, Y.H.; Kilgore, J.A.; Perez-Castro, L.; Braverman, J.; Borenstein-Auerbach, N.; Kim, M.; Lesner, N.P.; Mishra, P.; et al. MYC promotes tryptophan uptake and metabolism by the kynurenine pathway in colon cancer. Genes Dev. 2019, 33, 1236-1251. [CrossRef]

32. Singh, N.; Ecker, G.F. Insights into the structure, function, and ligand discovery of the large neutral amino acid transporter 1, LAT1. Int. J. Mol. Sci. 2018, 19, 1278. [CrossRef]

33. Tarlungeanu, D.C.; Deliu, E.; Dotter, C.P.; Kara, M.; Janiesch, P.C.; Scalise, M.; Galluccio, M.; Tesulov, M.; Schlessinger, A.; Indiveri, C.; et al. Impaired amino acid transport at the blood brain barrier is a cause of autism spectrum disorder. Cell 2016, 167, 1481-1494. [CrossRef]

34. Cascio, L.; Chen, C.F.; Pauly, R.; Srikanth, S.; Jones, K.; Skinner, C.D.; Stevenson, R.E.; Schwartz, C.E.; Boccuto, L. Abnormalities in the genes that encode large amino acid transporters increase the risk of autism spectrum disorder. Mol. Genet. Genomic Med. 2020, 8, e1036. [CrossRef] [PubMed]

35. Sivaprakasam, S.; Bhutia, Y.D.; Yang, S.; Ganapathy, V. Short-chain fatty acid transporters: Role in colonic homeostasis. Compr. Physiol. 2017, 8, 299-314.

36. Weksler, B.B.; Subileau, E.A.; Perriere, N.; Charneau, P.; Holloway, K.; Leveque, M.; Tricoire-Leignel, H.; Nicotra, A.; Bourdoulous, S.; Turowski, P.; et al. Blood-brain barrier-specific properties of a human adult brain endothelial cell line. FASEB J. 2005, 19, 1872-1874. [CrossRef] [PubMed]

37. Helms, H.C.; Abbott, N.J.; Burek, M.; Cecchelli, R.; Couraud, P.O.; Deli, M.A.; Forster, C.; Galla, H.J.; Romero, I.A.; Shusta, E.V.; et al. In vitro models of the blood-brain barrier: An overview of commonly used brain endothelial cell culture models and guidelines for their use. J. Cereb. Blood Flow Metab. 2016, 36, 862-890. [CrossRef]

38. Ohtsuki, S.; Ikeda, C.; Uchida, Y.; Sakamoto, Y.; Miller, F.; Glacial, F.; Decleves, X.; Scherrmann, J.M.; Couraud, P.O.; Kubo, Y.; et al. Quantitative targeted absolute proteomic analysis of transporters, receptors and junction proteins for validation of human cerebral microvascular endothelial cell line hCMEC/D3 as a human blood-brain barrier model. Mol. Pharm. 2013, 10, 289-296. [CrossRef] [PubMed] 
39. Pierre, K.; Pellerin, L. Monocarboxylate transporters in the central nervous system: Distribution, regulation and function. J. Neurochem. 2005, 94, 1-14. [CrossRef]

40. Bergersen, L.H. Lactate transport and signaling in the brain: Potential therapeutic targets and roles in body-brain interaction. J. Cereb. Blood Flow Metab. 2015, 35, 176-185. [CrossRef]

41. Contreras-Baeza, Y.; Sandoval, P.Y.; Alarcon, R.; Galaz, A.; Cortes-Molina, F.; Alegria, K.; Baeza-Lehnert, F.; Arce-Molina, R.; Guequén, A.; Flores, C.A.; et al. Monocarboxylate transporter 4 (MCT4) is a high affinity transporter capable of exporting lactate in high-lactate microenvironments. J. Biol. Chem. 2019, 294, 20135-20147. [CrossRef]

42. Roberts, L.M.; Black, D.S.; Raman, C.; Woodford, K.; Zhou, M.; Haggerty, J.E.; Yan, A.T.; Cwirla, S.E.; Grindstaff, K.K. Subcellular localization of transporters along the rat blood-brain barrier and blood-cerebral-spinal fluid barrier by in vivo biotinylation. Neuroscience 2008, 155, 423-438. [CrossRef] [PubMed]

43. Huang, C.K.; Chang, P.H.; Kuo, W.H.; Chen, C.L.; Jeng, Y.M.; Chang, K.J.; Shew, J.Y.; Hu, C.M.; Lee, W.H. Adipocytes promote malignant growth of breast tumours with monocarboxylate transporter 2 expression via $\beta$-hydroxybutyrate. Nat. Commun. 2017, 8, 14706. [CrossRef] [PubMed]

44. Goncalves, P.; Gregorio, I.; Martel, F. The short-chain fatty acid butyrate is a substrate of breast cancer resistance protein. Am. J. Physiol. Cell Physiol. 2011, 301, C984-C994. [CrossRef] [PubMed] 